\title{
FORECASTING MONTHLY NAUTICAL CHART TIME SERIES OF JAVA AREA USING ARIMA METHOD (Case study: Primkopal Pushidrosal Sales Units) \\ Benny Rushadi ${ }^{1)}$, Sulistyo Puspitodjati ${ }^{2}$ \\ Magister Manajemen Sistem Informasi, Universitas Gunadarma \\ Jl. Kenari nomor 13 Jakarta Pusat, 10430 \\ 1bennyerros82@gmail.com, 22 sulistyo@staff.gunadarma.ac.id
}

\begin{abstract}
Nautical chart is a sea map made from paper and has a function to safety of navigation at sea as it provides vital information such as configuration of the coastline, depth of the sea, seabed nature, hazardous location, height and navigation aids. Sailing at sea and on the waters are not always safe as many navigational hazards threaten at any time, therefore the role of nautical charts is essential. Inaccuracy in estimating the number of nautical chart production has affected the amount of stockpiles in the warehouse, this is very inefficient for sales unit of Primkopal Pushidrosal. Consequently, the making of an appropriate forecasting model to predict the amount of stock in the coming period is expected to overcome these problems. The data which had been used in this research is Indonesian nautical chart sales from January 2012 to March 2019 in the Java area for 87 periods from January 2012 to March 2019 to predict the number of product requests for the coming 8 periods from April to November 2019, as the most densely sea traffic hence nautical charts in this area are the most utilized. The quantitative analysis of the model uses the Integrated Moving Average Autoregressive (ARIMA) method approach where the stages are from identification of model, estimation of parameter and diagnostic tests, because this method is good enough to predict short-term periods and is suitable for predicting the magnitude of any variable in time series data. Processing data uses Minitab 17 software and the results of the research showed that 87 of these periods where the data has not been stationer against mean, so it must be differentiated level 1 in order to be stationary and the ARIMA model is $\operatorname{ARIMA}(0,1,1)$ by equation $X t=-0.551+X t-1-0.85 e t-1$.
\end{abstract}

Keywords: Forecasting, Nautical chart, ARIMA.

\section{Abstrak}

Nautical chart merupakan sebuah peta laut berbahan dasar dari kertas untuk keselamatan dalam bernavigasi di laut, memberikan beberapa informasi seperti konfigurasi garis pantai, kedalaman laut, sifat dasar laut, lokasi bahaya, ketinggian dan sarana bantu navigasi. Dalam pelayaran di laut maupun di perairan tidak selamanya aman, banyak bahaya navigasi yang sewaktu-waktu mengancam sehingga peran nautical chart sangat dibutuhkan. Ketidaktepatan dalam memperkirakan jumlah produksi nautical chart telah berimbas terhadap jumlah tumpukan stok di gudang, hal demikian sangat tidak efisiensi terhadap unit penjualan Primkopal Pushidrosal. Oleh karena itu, diharapkan pembuatan model peramalan yang tepat untuk meramalkan jumlah persediaan stok periode mendatang dapat membantu mengatasi permasalahan tersebut. Data yang digunakan dalam penelitian ini menggunakan data penjualan nautical chart Indonesia wilayah Jawa selama 87 periode mulai Januari 2012 sampai Maret 2019 untuk meramalkan jumlah permintaan produk 8 periode mendatang bulan April sampai November 2019, sebagaimana wilayah ini merupakan wilayah yang paling padat lalu lintas lautnya sehingga nautical chart pada wilayah inilah yang paling banyak digunakan. Analisis kuantitatif model mengunakan metode Autoregresif Integrated Moving Average (ARIMA) yang mana tahapannya mulai dari identifikasi model, estimasi parameter dan tes diagnostik, karena metode ini cukup bagus untuk meramalkan periode jangka pendek 
dan cocok untuk meramalkan besaran variabel apapun dalam data time series. Pengolahan menggunakan software Minitab 17 dan hasil penelitian menunjukan bahwa 87 periode ini tidak stasioner terhadap rata-rata sehingga harus dideferensiasi tingkat 1 agar data menjadi stasioner serta didapatkan model ARIMA yaitu $\operatorname{ARIMA}(0,1,1)$ dengan persamaan $X_{t}=-$ $0.551+X_{t-1}-0.85 e_{t-1}$.

Kata Kunci : Peramalan, Nautical chart, ARIMA.

\section{Pengantar}

Informasi merupakan faktor penting yang dibutuhkan bagi semua orang, khususnya informasi mengenai hidrografi dan oseanografi sangat dibutuhkan bagi Pelaut, Civitas akademisi pelayaran dan kelautan, Birokrat daerah yang terkait dengan maritim ataupun Praktisi dan Stake holder lainya.

Pushidrosal merupakan lembaga hidrografi nasional mempunyai tugas menyelenggarakan pembinaan hidro-oseanografi yang meliputi survei, penelitian, pemetaan laut, publikasi, penerapan lingkungan laut dan keselamatan navigasi pelayaran baik untuk kepentingan TNI maupun kepentingan umum serta menyiapkan data dan informasi wilayah pertahanan di laut dalam rangka mendukung tugas pokok TNI Angkatan Laut [1].

Salah satu produk yang diproduksi oleh Pushidrosal yaitu nautical chart Indonesia yang diakui oleh International Hydrographic Organization (IHO) dan bersertifikat hak cipta produk [1]. Nautical chart adalah salah satu alat paling mendasar yang tersedia untuk keselamatan bernavigasi berupa peta yang menggambarkan konfigurasi garis pantai dan dasar laut serta memberikan informasi kedalaman air, lokasi bahaya untuk navigasi, karakteristik alat bantu untuk navigasi, lokasi, tempat lego, dan fitur lainnya [2]. Sesuai [3] kenavigasian diselenggarakan untuk menjamin keamanan dan keselamatan pelayaran, mendorong kelancaran kegiatan perekonomian, menandai batas wilayah dalam rangka menjaga kedaulatan, memantapkan pertahanan dan keamanan negara, serta memperkukuh persatuan kesatuan bangsa dalam kerangka wawasan nusantara.

Tabel 1 berikut merupakan salah satu contoh wilayah di laut jawa yang menunjukan betapa padatnya pelayaran kapal di Selat sunda dari tahun 2007 - 2015, disinilah peran nautical chart dibutuhkan untuk keselamatan dalam pelayaran.

Tabel 1. Jumlah Pelayaran di Selat Sunda dari tahun 2007 sampai 2015

(Sumber: Puskodal Lanan Banten)

\begin{tabular}{|c|c|c|c|c|c|c|c|c|c|c|c|}
\hline \multirow{2}{*}{ No } & \multirow{2}{*}{ JENIS KAPAL } & \multicolumn{10}{|c|}{ TAHUN } \\
\hline & & 2007 & 2008 & 2009 & 2010 & 2011 & 2012 & 2013 & 2014 & 2015 & JUMLAH \\
\hline \multirow{2}{*}{$\begin{array}{l}1 \\
2\end{array}$} & \multirow{2}{*}{$\begin{array}{l}\text { KRI (Kapal Perang RI) } \\
\text { KAL (Kapal Angkatan } \\
\text { Laut) }\end{array}$} & 48 & 19 & 38 & 16 & 30 & 16 & 38 & 42 & 168 & 415 \\
\hline & & & & 2 & & 5 & & & & 0 & 7 \\
\hline 3 & Kapal Perang Asing & 2 & 4 & 3 & 9 & 6 & 7 & 1 & 3 & 6 & 41 \\
\hline 4 & Kapal Kargo & 962 & 741 & 744 & 689 & 668 & 3957 & 3803 & 2663 & 2339 & 16566 \\
\hline 5 & Kapal Tangker & 505 & 442 & 618 & 509 & 403 & 2550 & 2873 & 1780 & 1465 & 11145 \\
\hline 6 & Kapal Kontainer & 128 & 99 & 118 & 64 & 62 & & & & 65 & 536 \\
\hline 7 & Kapal Pesiar & - & & 7 & 4 & 5 & 3 & & & 0 & 19 \\
\hline 8 & Kapal Feri & 4 & 2 & 3 & 35 & 30 & 85 & 57 & 32 & 25 & 273 \\
\hline 9 & Kapal Tunda (Tug Boat) & 27 & 53 & 53 & 1 & 1 & & & & 0 & 135 \\
\hline 10 & Kapal Tongkang & - & 1 & & 15 & 14 & & & & 0 & 30 \\
\hline 11 & Kapal Survei & - & & 8 & 8 & 19 & & & & 0 & 35 \\
\hline 12 & Kapal Ikan Indonesia & 6 & 12 & 19 & 8 & 10 & & 3 & 1 & 0 & 59 \\
\hline 13 & LCT & & & 33 & 1 & & 3 & 2 & & 0 & 39 \\
\hline \multirow{3}{*}{$\begin{array}{l}14 \\
15\end{array}$} & KPLP & & & 3 & 1 & & & 1 & & 0 & 5 \\
\hline & $\begin{array}{l}\text { Tdk Teridentifikasi } \\
\text { Jenisnya }\end{array}$ & 4 & 1 & 3 & 2 & & & 16 & 20 & 37 & 83 \\
\hline & JUMLAH & 1686 & 1374 & 1652 & 1362 & 1253 & 6621 & 6794 & 4541 & 4105 & 29388 \\
\hline
\end{tabular}


Nautical chart Indonesia terbagi dalam 8 wilayah yaitu wilayah A (Sumatera), Wilayah B (Kalimantan), Wilayah C (Jawa), Wilayah D (Kalimantan dan Sulawesi), Wilayah E (Nusatenggara), Wilayah F (P.P. Maluku), Wilayah G (Pulau-pulau Sermata, Pulau Tanimbar, Pulau-pulau Kai, Pulau-pulau Aru, Laut Banda dan Laut Arafuru) dan Wilayah H (Papua). Pada produk nautical chart terdapat posisi Lintang dan Bujur serta ukuran yang disebut dengan sekala, dimana terdapat 2 (dua) ukuran sekala yaitu peta sekala kecil dan peta sekala besar. Peta sekala kecil memiliki sekala 1:500.000 sampai 1:4.000.000 yang menggambarkan ukuran daerah yang cukup luas dan sekala besar sebaliknya memiliki sekala 1:5000 sampai 1:250.000 yang menggambarkan ukuran daerah yang sempit atau relatif tidak luas (lebih detail) [4], walapun sudah ada Electronic Navigation Chart (ENC) berupa peta laut elektronik, nautical chart berbahan kertas tetap masih dibutuhkan sebagai pembanding karena penggunaannya yang tidak tergantung pada arus listrik karena bersifat konvensional.

Proses cetak nautical chart dalam bentuk kertas merupakan program kerja rutin tahunan Pushidrosal yang dilaksanakan oleh Dinas Produksi dan Distribusi (Disprodisi) serta cetak nautical chart juga dilakukan jika ada perubahan secara spesifik pada suatu peta yang perlu update ataupun dikarenakan stok kosong di gudang, ketidaktepatan pencetakan nautical chart telah berimbas terhadap jumlah tumpukan stok di gudang, hal demikian sangat tidak efisiensi serta dapat menimbulkan resiko rusaknya produk yang disimpan di gudang akibat penyimpanan terlalu lama. Kontribusi dan tujuan dari penelitian ini yaitu dihasilkan suatu model peramalan bagi unit penjualan Primkopal Pushidrosal untuk meramalkan jumlah penjualan untuk bulan April sampai November 2019 menggunakan model ARIMA sehingga dapat membantu mengurangi kerugian yang tidak diinginkan dan mengatasi permasalahan penumpukan stok di gudang serta dapat dimanfaatkan sebagai rekomendasi bagi pimpinan untuk pengambilan kebijakan.

Menurut [5] metode ARIMA menawarkan teknik peramalan yang baik, cocok untuk meramalkan besaran variabel apapun dalam data runtun waktu (times series), begitu juga menurut [6] metode ARIMA tidak membutuhkan adanya asumsi tentang suatu pola yang tetap sehingga berbeda dengan metode lainnya.

Analisis time series merupakan salah satu prosedur statistika yang diterapkan untuk meramalkan probabilitas keadaaan yang akan datang dalam rangka pengambilan keputusan. Model runtun waktu yang paling popular dan banyak digunakan dalam peramalan data runtun berkala adalah model autoregressive integrated moving average atau yang dikenal dengan model ARIMA [7].

Data time series untuk model ARIMA harus bersifat stasioner baik stasioner terhadap varian maupun mean dan tidak mengandung trend, musiman atau berfluktuasi ekstrim, jika suatu data time series tidak stasioner maka data tersebut harus di deferensiasi sampai menghasilkan data yang stasioner dengan maksimal deferensiasi sebanyak tiga kali.

Penelitian sebelumnya yang dilakukan oleh [5] menggunakan metode ARIMA untuk analisis peramalan jumlah kejahatan dengan data pemalsuan mata uang palsu selama 96 bulan dan diolah menggunakan software Gnu Regression, Econometrics and Time-series Library (GRETL), hasil yang didapat yaitu didapatkan model ARIMA (1,1,1). Penelitian [6] melakukan penelitian tentang peramalan vaksin imunisasi di Puskesmas XYZ dengan data permintaan jumlah vaksin campak selama 12 bulan dan diolah menggunakan Eviews 9.5, hasil yang didapat yaitu model ARIMA $(0,1,1)$.

Merujuk pada kedua penelitian sebelumnya maka dalam penelitian ini menggunakan metode ARIMA untuk menghasilkan model peramalan jumlah penjualan nautical chart menggunakan data historis penjualan sebanyak 87 bulan yang didapatkan langsung dari unit penjualan Primkopal Pushidrosal mulai periode Januari 2012 sampai Maret 2019 dan pengolahan berbeda dari penelitian sebelumnya yaitu menggunakan software Minitab 17. 


\section{Metodologi Penelitian}

\subsection{Model ARIMA}

Metode Box-Jenkins atau disebut Autoregressive Integrated Moving Average (ARIMA) merupakan salah satu teknik peramalan dengan pendekatan deret waktu yang menggunakan teknik-teknik korelasi antar suatu deret waktu. Dasar pemikiran dari model ARIMA adalah pengamatan sekarang $(\mathrm{Zt})$ tergantung pada satu atau beberapa pengamatan sebelumnya (Zt-k). Dengan kata lain, model ini dibuat karena secara statis ada korelasi (dependen) antar deret pengamatan. Untuk melihat adanya dependensi antar pengamatan, dapat melakukan uji korelasi antar pengamatan yang sering dikenal dengan fungsi autokorelasi [8]. Tahapan pada penelitian ini, mengikuti tahapan pemodelan peramalan dengan ARIMA terdiri dari identifikasi model, estimasi parameter dan tes diagnostik.

Model ARIMA pada umumnya ditulis ARIMA $(p, d, q)$ dimana memiliki arti Autoregressive $\operatorname{AR}(p)$, differencing $d$, dan Moving Average $\operatorname{MA}(q)$ [9].

\subsection{Proses Autoregressive}

Model Autoregressive (AR) dengan orde p dinotasikan dengan AR(p). Bentuk umum model AR(p) adalah:

$$
X_{t}=\mu+\phi_{1} X_{t-1}+\cdots+\phi_{p} X_{t-p}+e_{t}[10]
$$

dimana $X_{t}$ adalah nilai variabel pada berkala ke-t, $\mu$ adalah nilai konstanta, $\phi_{i}$ adalah parameter autoregressive ke i: $1,2,3, \ldots ., p, e_{t}$ adalah nilai galat pada berkala ke- $t$.

\subsection{Proses Integrated}

Data time series dapat dikatakan sudah stasioner jika stasioner dalam rata-rata dan stasioner dalam variansi memiliki fluktuasi data yang tetap atau konstan, tidak ada unsur trend dan musiman dalam data.

Menurut [10] apabila dalam identifikasi data dengan cara plot time series tidak dihasilkan data stasioner maka data time series perlu dilakukan modifikasi sampai dihasilkan data yang stasioner, hal ini dapat dicapai secara rutin melalui proses integrated dengan penggunaan metode differencing. Proses terintegrasi didefinisikan oleh persamaan:

$$
X_{t}^{\prime}=X_{t}-X_{\mathrm{t}-1} \quad[10]
$$

dimana $X_{t}$ adalah nilai variabel awal dan $X_{t}^{\prime}$ adalah deret baru pada pembedaan pertama.

\subsection{Proses Moving Average}

Moving average juga disebut distributed lag model karena model regresinya melibatkan selisih nilai dari variabel sekarang dengan nilai dari variabel sebelumnya $\left(a_{t-p}\right)$ [9].

Model Moving Average dengan orde $q$ dinotasikan dengan $\operatorname{MA}(q)$ dapat didefinisikan sebagai:

$$
X_{t}=\mu+e_{t}-\Theta_{1} e_{t-1}-\cdots-\Theta_{q} e_{t-q}[10]
$$

dimana $X_{t}$ adalah nilai variabel pada berkala ke-t, $\mu$ adalah nilai konstanta, $\Theta_{\mathrm{i}}$ adalah parameter moving average ke i: $1,2,3, \ldots, q, e_{t-k}$ adalah nilai galat pada saat $t-k$.

Berikut merupakan diagram alir dalam tahapan yang dilakukan dalam proses pembuatan model ARIMA yaitu: 


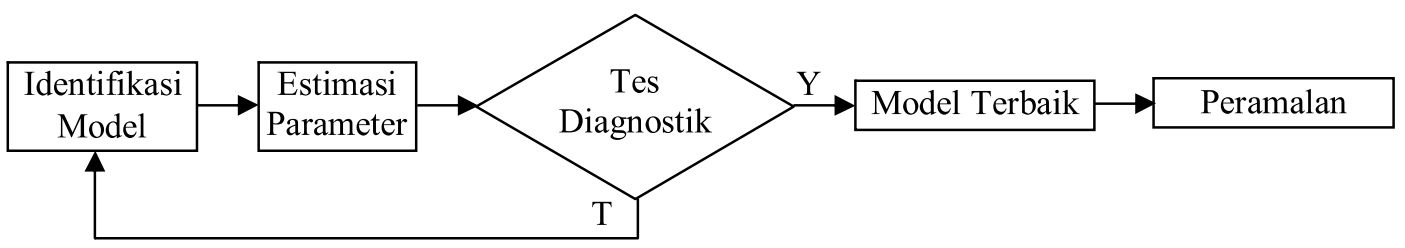

Gambar 1. Diagram alir tahapan pemodelan ARIMA

Menurut [9] dalam pemodelan ARIMA sesuai gambar 1 dibutuhkan beberapa tahapan dalam prosedur pembentukan model ARIMA yaitu identifikasi model, estimasi parameter dan tes diagnostik. Dalam identifikasi model yang perlu diperhatikan adalah memplot data kedalam bentuk grafik, data time series tersebut harus bersifat stasioner terhadap varian dan mean, jika data tidak stasioner maka dilakukan transformasi dan differencing. Fungsi ACF dan PACF digunakan untuk mengidentifikasi order $p$ dan $q$, selama dalam langkah identifikasi, tahapan ini harus menghasilkan time series stasioner, yang merupakan kondisi yang diperlukan untuk menemukan model ARIMA. Pada tahap estimasi parameter dilakukan tahap pencarian nilai awal pada parameter-parameter dari identifikasi model yang didapat, pada umumnya estimasi ini dapat menggunakan metode kuadrat terkecil atau metode estimasi tidak linier. Pada tahap tes diagnostik untuk memastikan apakah modelnya cocok dengan data yang ada dengan mengamati residual dari model white noise jika tidak cocok maka kembali lagi ke tahap identifikasi model sampai didapatkan model yang terbaik untuk peramalan.

\section{Hasil dan Pembahasan}

Dalam artikel ini ditunjukan data real penjualan nautical chart wilayah Jawa yang didapat dari unit penjualan peta laut Pushidrosal yang dapat ditunjukan dalam grafik sebagai berikut.

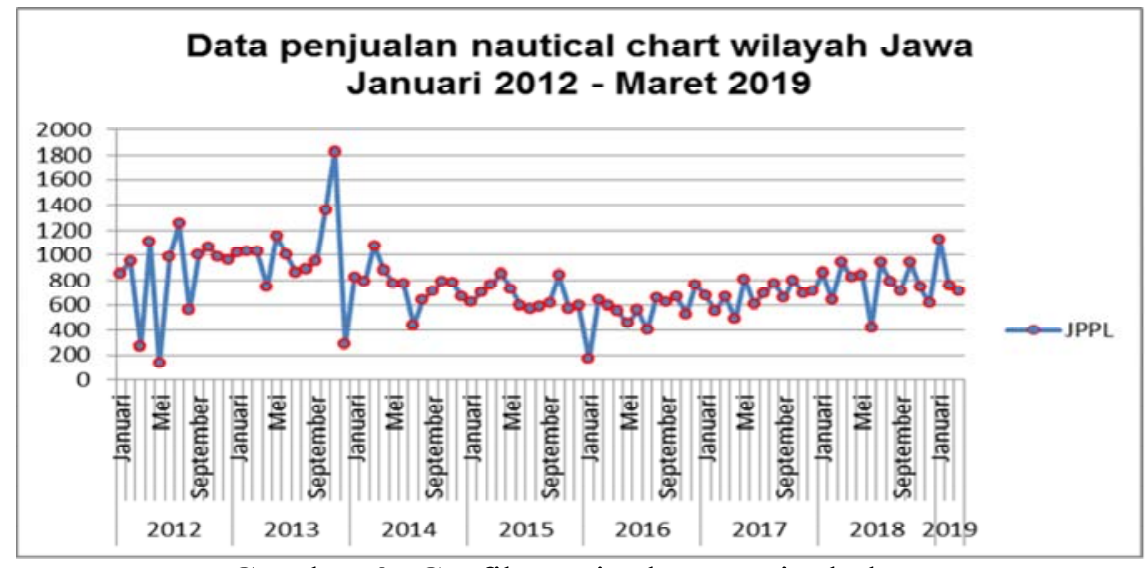

Gambar 2. Grafik penjualan nautical chart

Berdasarkan bahasan yang sudah diuraikan di atas, pengolahan akan dilakukan dalam tiga tahapan yaitu identifikasi model, estimasi parameter, dan tes diagnostik. Model yang ditunjukkan pada Gambar 2 didasarkan pada permintaan produk akhir dalam penjualan nautical chart wilayah Jawa dari Januari 2012 sampai Maret 2019.

\subsection{Identifikasi Model}

Pada tahapan identifikasi model, merupakan langkah awal proses melihat kestasioneran dari data, kemudian menentukan nilai dari AR dan MA dengan melihat plot ACF dan PACF, dalam identifikasi data dapat dilakukan dengan cara plot data historis sebagaimana terlihat pada gambar 3 berikut. 


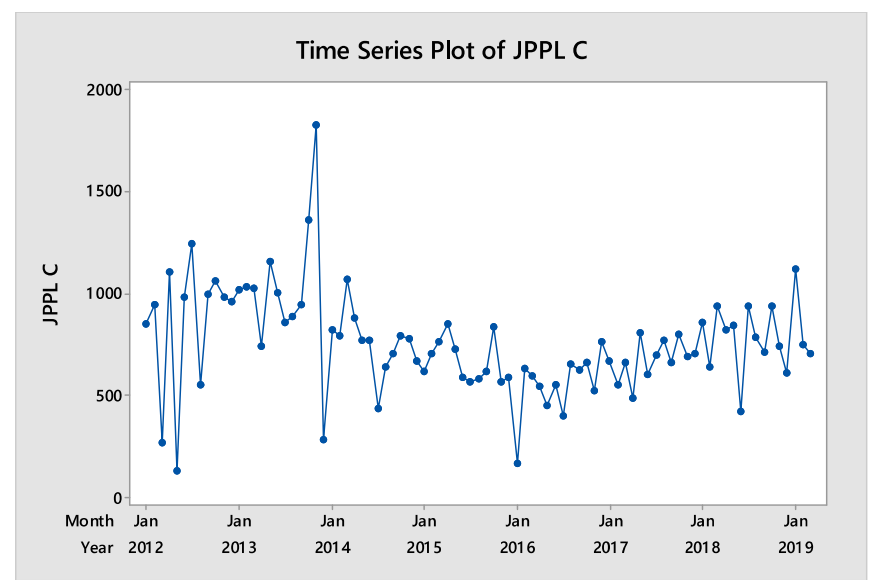

Gambar 3. Time series plot data awal

Berdasarkan plot data time series pada gambar 3 terlihat bahwa data time series penjualan produk nautical chart berfluktuasi diluar rata-rata dan cenderung memiliki tren menurun (terlihat pada gambar 4) sehingga dapat disimpulkan data tersebut non stasioner terhadap rata-rata sehingga harus dideferensiasi agar menghasilkan data yang stasioner, namun data time series tersebut sudah stasioner terhadap varian yang mana dapat ditunjukan pada gambar 5 yang memiliki Rounded value 1 dalam tingkat kepercayaan 95\%.

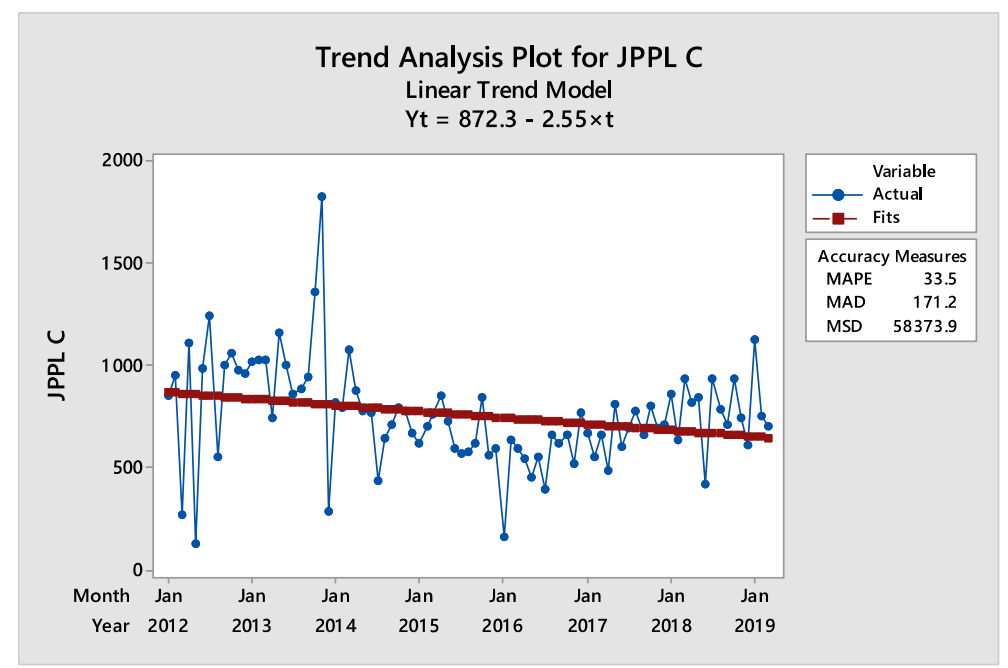

Gambar 4. Tren analisis data

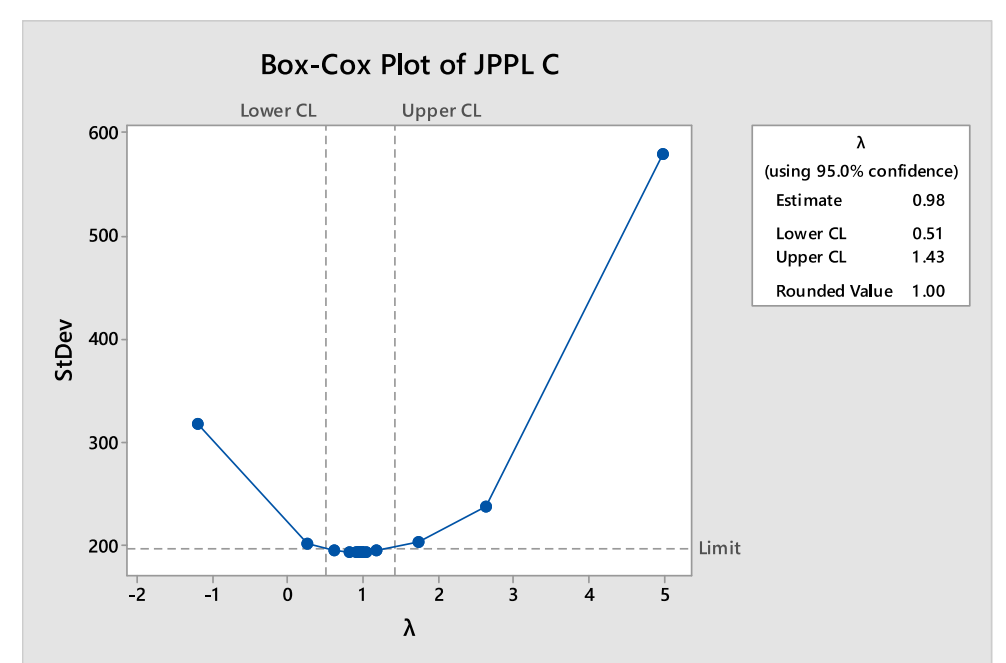

Gambar 5. Uji stasioneritas terhadap varian data awal 
Dikarenakan data bersifat non stasioner terhadap mean maka akan dilakukan diferensiasi tingkat satu untuk data awal, sehingga dapat terlihat pada gambar 6 bahwa plot data diferensiasi tingkat satu sudah stasioner terhadap mean.

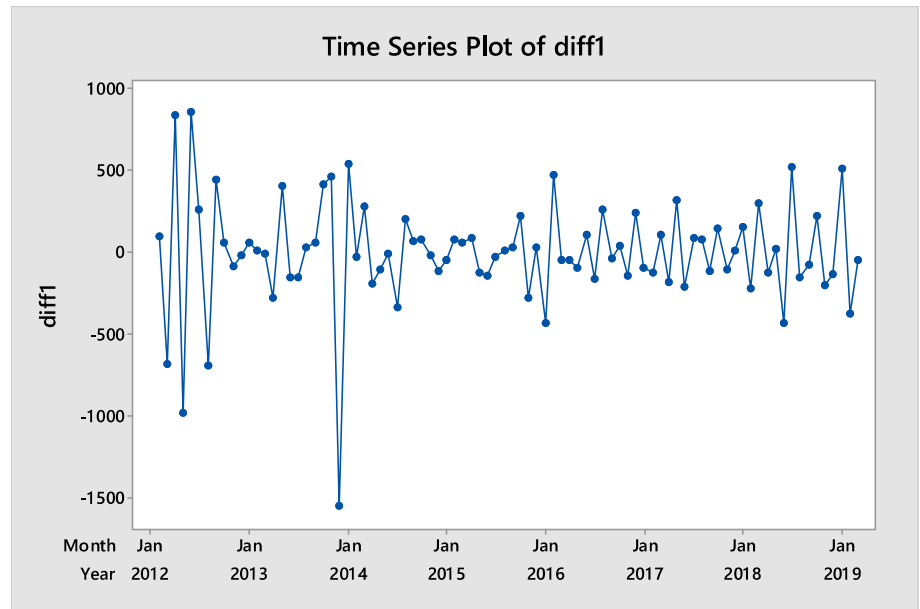

Gambar 6. Plot data diferensiasi tingkat satu data time series

Terlihat pada gambar 6 bahwa grafik sudah menunjukan kestasioneran dalam mean dan varian, dengan demikian data time series ini sudah dapat digunakan untuk membuat model ARIMA. Setelah dilakukan diferensiasi tingkat satu maka telah didapatkan order $d(1)$, sehingga model ARIMA sementara yaitu ARIMA $(p, 1, q)$. Selanjutnya mencari order $p$ dan $q$ dengan melakukan uji korelasi data time series yaitu dengan fungsi autokorelasi (ACF) dan fungsi autokorelasi parsial (PACF) yang dapat ditunjukan pada gambar 7 dan gambar 8 berikut.

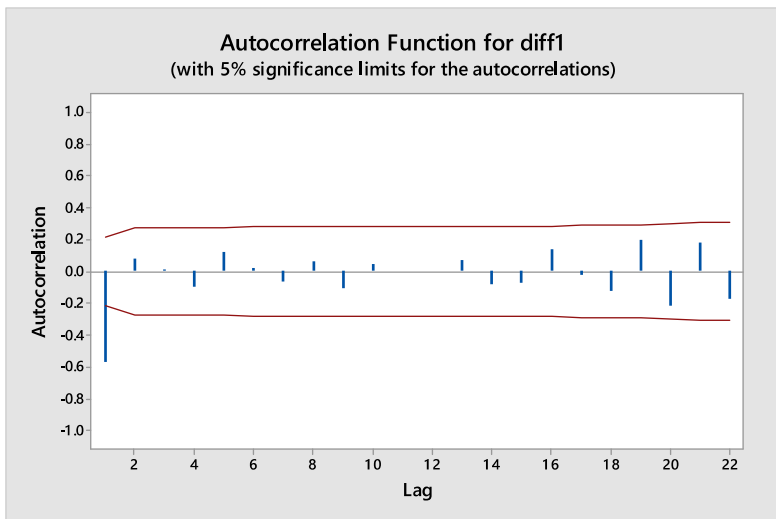

Gambar 7. Plot ACF data diferensiasi satu

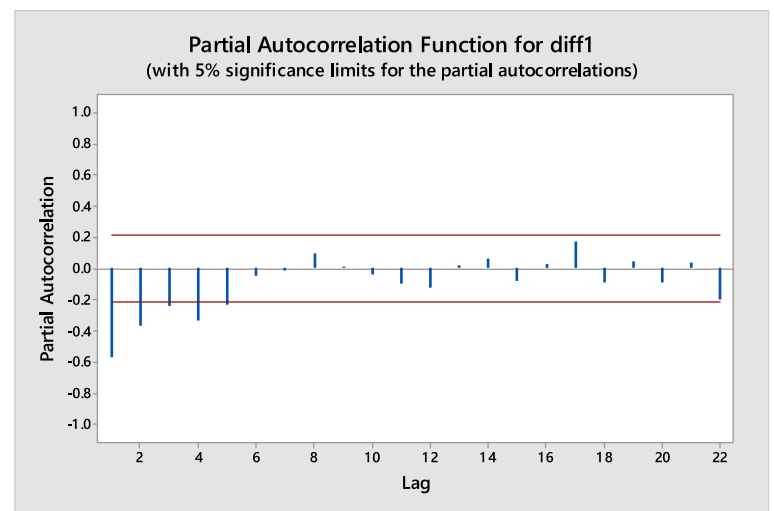

Gambar 8. Plot PACF data diferensiasi satu 
Jumlah lag pada data time series yang ditunjukan pada ACF dan PACF merupakan banyaknya jumlah data dibagi empat yaitu $n / 4=87 / 4=22$ lag. Pada gambar 7 dan gambar 8 menunjukkan besaran korelasi antar deret waktu antara ke-22 lag. Correlogram menampilkan uji hipotesis $\rho_{k}$ dalam selang kepercayaan 95\% untuk toleransi $\alpha=5 \%$, dimana hipotesisnya sebagai berikut.

$\mathrm{h}_{0}: \rho_{k}=0$

$\mathrm{h}_{1}: \rho_{k} \neq 0$

sehingga apabila terima $\mathrm{h}_{0}$ maka data dianggap sudah stasioner. Gambar 7 plot ACF terlihat bahwa pada lag 1 bernilai -0.57 berbeda secara signifikan dari nilai 0 dengan tingkat keyakinan 5\%, sedangkan gambar 8 plot PACF menunjukan bahwa correlogram dying down.

Berdasarkan pengamatan terhadap ACF dan PACF maka telah didapatkan model MA yaitu order $q(1)$, sehingga model ARIMA sementara yaitu ARIMA $(0,1,1)$.

\subsection{Estimasi Parameter}

Setelah identifikasi model awal ARIMA didapat, langkah berikutnya tahap estimasi parameter yaitu besaran koefisien $\operatorname{AR}(\phi)$ dan MA $(\theta)$. Besaran koefisien didapatkan dengan cara trial error dengan membandingkan Mean Squared Error (MSE) terkecil dari kedua parameter tersebut. Gambar 8 berikut merupakan hasil estimasi parameter menggunakan bantuan software statistik.

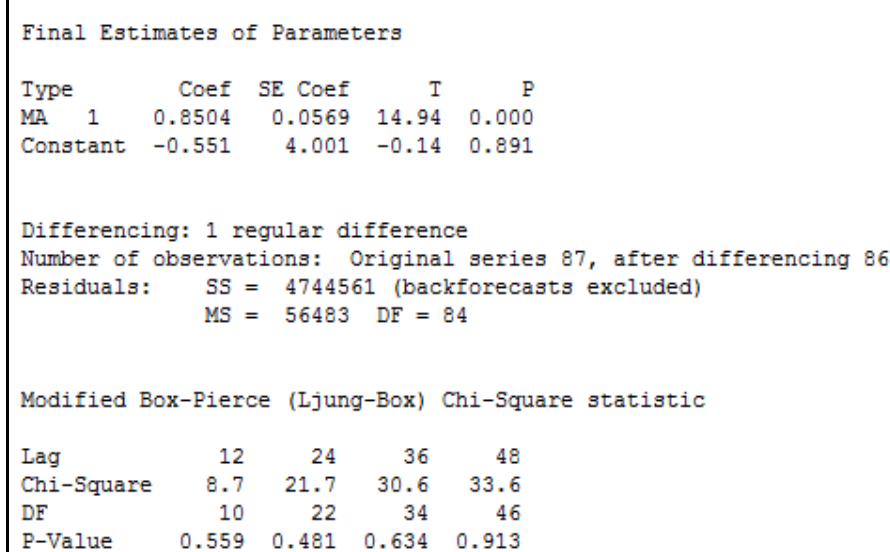

Gambar 9. Hasil estimasi parameter

Berdasarkan gambar 9 didapat nilai P-value pada parameter MA sudah signifikan, maka terima hipotesis $\mathrm{h}_{0}$ dengan nilai koefisien MA yaitu 0.85 dengan Mean Square 56483. Jadi, persamaan model ARIMA yang didapat yaitu $X_{t}=\mu+X_{t-1}-\Theta_{1} e_{t-1}$.

\subsection{Tes Diagnostik}

Pada tahapan ini dilakukan tahap plot kenormalan probabilitas data dan mendeteksi adanya korelasi antar residual, sehingga residual mengikuti proses white noise yaitu jika urutan variabel acak tidak berkorelasi dari distribusi tetap dengan rata-rata konstan. 


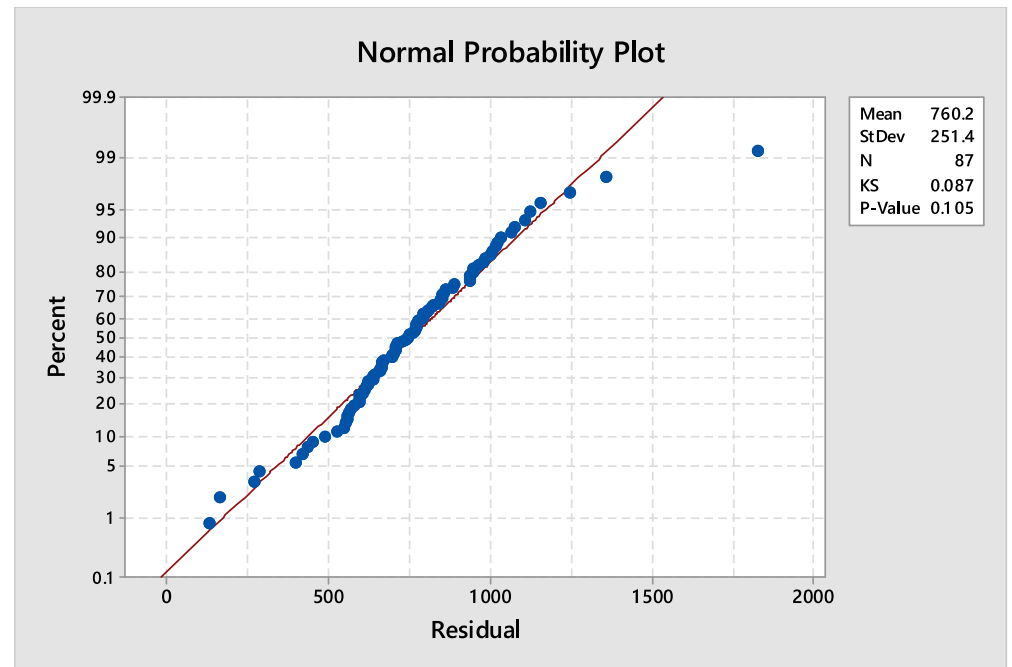

Gambar 10. Plot Uji Kenormalan Residual

Berdasarkan gambar 10 dapat diambil kesimpulan bahwa deret data telah berdistribusi normal dengan melihat $\mathrm{p}$-value melebihi 0,05 dan deret data menunjukkan posisi disekitar garis.

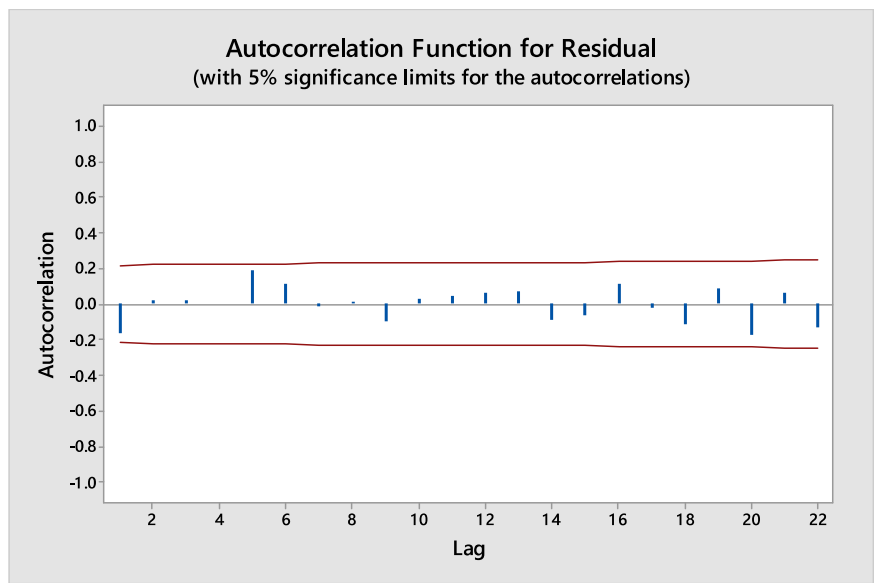

Gambar 11. ACF Residual Model ARIMA $(0,1,1)$

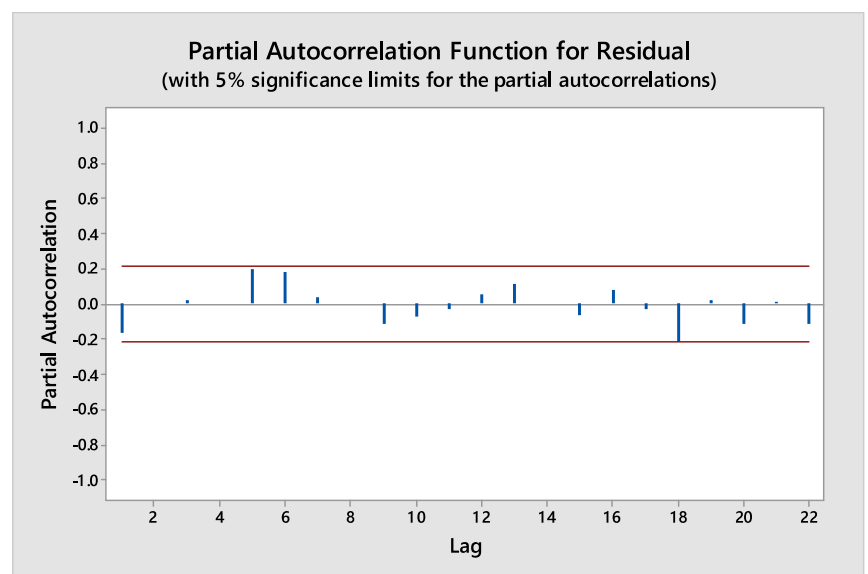

Gambar 12. PACF Residual Model ARIMA $(0,1,1)$

Berdasarkan gambar 11 dan gambar 12 terlihat semua lag tidak berkorelasi secara keseluruhan, sehingga dapat disimpulkan bahwa residual telah memenuhi asumsi independensi, sedangkan pada uji Ljung-Box yaitu pada lag 12, 24, 36, 48 berturut-turut nilai 
P-Value yaitu $0.559,0.481,0.634,0.913$ berada pada angka diatas nilai toleransi $(\alpha)$ adalah $5 \%$ sehingga model ARIMA $(0,1,1)$ yang didapat sudah cukup memadai untuk dijadikan model peramalan produk nautical chart. Gambar 13 berikut merupakan hasil peramalan jumlah permintaan untuk 8 periode mendatang bulan April sampai November 2019.

\begin{tabular}{|cccccccc|}
\hline \multicolumn{10}{|c|}{ Forecasts from period 87} \\
\multicolumn{10}{|c|}{ 95 Limits } \\
\multicolumn{10}{c}{ Period Forecast } & Lower & Upper & Period Forecast & Lower & Upper \\
88 & 779.80 & 313.89 & 1245.71 & 92 & 777.60 & 291.29 & 1263.91 \\
89 & 779.25 & 308.16 & 1250.34 & 93 & 777.05 & 285.78 & 1268.32 \\
90 & 778.70 & 302.49 & 1254.92 & 94 & 776.50 & 280.31 & 1272.69 \\
91 & 778.15 & 296.86 & 1259.44 & 95 & 775.95 & 274.89 & 1277.01 \\
& & & & & & & \\
\hline
\end{tabular}

Gambar 13. Hasil Peramalan

\section{Kesimpulan}

Hasil penelitian ini sebagai sistem acuan bagi unit penjualan Primkopal Pushidrosal untuk diterapkan dalam persediaan stok nautical chart menggunakan model peramalan persediaan stok produk nautical chart wilayah Jawa yaitu model ARIMA $(0,1,1)$ dengan tingkat kesalahan Mean Square sebesar 56483 serta dinotasikan dalam persamaan $X_{t}=-$ $0.551+X_{t-1}-0.85 e_{t-1}$, dengan hasil peramalan jumlah penjualan produk untuk 8 periode mendatang (gambar 13) menunjukan trend menurun, berbeda model dengan penelitian sebelumnya dalam analisis peramalan jumlah kejahatan didapatkan model ARIMA $(1,1,1)$ sedangkan penelitian tentang analisis peramalan jumlah vaksin imunisasi dihasilkan model ARIMA $(0,1,1)$ dengan nilai parameter dan software yang berbeda

\section{Daftar Pustaka}

[1] Pusat Hidrografi dan Oseanografi TNI Angkatan Laut. (2019). Sejarah Pushidrosal sebagai lembaga Hidrografi Nasional Indonesia. Pushidrosal. Jakarta.

[2] NOAA, What is a Nautical chart?, NOAA, online: https://oceanservice.noaa.gov/facts/nautical_chart.html Diakses 30 November 2019.

[3] Peraturan Presiden No.5 Tahun 2010 tentang Kenavigasian.

[4] Pusat Hidrografi dan Oseanografi TNI Angkatan Laut. (2017). Nautical charts and publications catalogue. Pushidrosal. Jakarta.

[5] Shrivastav, A.K., dan Ekata. (2014). Applicability of Box Jenkins ARIMA Model in Crime Forecasting: A case study of counterfeiting in Gujarat State. International Journal of Advanced Research in Computer Engineering \& Technology, 494-497.

[6] Putri, N.I., Wirawan, A.A., Khofiyah, N.A., Yuniaristanto. (2018). Peramalan Kebutuhan Jumlah Vaksin Imunisasi Campak Dengan Menggunakan Metode ARIMA: Studi Kasus. Seminar dan Konferensi Nasional IDEC 2018 Surakarta, 7-8 Mei 2018, ISSN:2579-6429.

[7] Sari, D.R., Sugito dan Ispriyanti, D. (2015). Peramalan Indeks Harga Konsumen Menggunakan Model Intervensi Fungsi STEP, Jurnal Gaussian, vol.4, no.4, ISSN:2339-254, 795-804.

[8] Iriawan, N. dan Astuti, S.P. (2006). Mengolah Data Statistik dengan Mudah Menggunakan Minitab 14. Penerbit Andi. Yogyakarta.

[9] Muis, S. (2008). Meramal Pergerakan Harga Saham Menggunakan Pendekatan Model ARIMA, Indeks Tunggal \& Markowitz. Graha Ilmu. Yogyakarta.

[10] Makridakis, S., Wheelwright, S.C., and McGee, V.E. Metode dan Aplikasi Peramalan jilid I (Edisi Revisi). Bina Rupa Aksara. Jakarta. 